\title{
Nitrogen Availability in Pecan Orchard Soil: Implications for Pecan Fertilizer Management
}

\author{
M. Lenny Wells ${ }^{1}$ \\ Department of Horticulture, University of Georgia, Tifton Campus, 4604 \\ Research Way, Tifton, GA 31793 \\ Additional index words. Carya illinoinensis, legumes, clover, poultry litter
}

\begin{abstract}
Nitrogen (N) fertilizer application to plants at rates not adjusted for the $\mathbf{N}$ contribution from soil $\mathbf{N}$ availability may result in overapplication of fertilizer. Further understanding of proper timing of $\mathrm{N}$ applications based on soil $\mathrm{N}$ dynamics and plant demand can be valuable information for the efficient use of fertilizer $N$. The present study measures soil $\mathbf{N}$ dynamics in a pecan orchard under various $\mathbf{N}$ fertilizer regimes on a southeastern U.S. Coastal Plain soil. The following treatments were evaluated: 1) crimson clover (Trifolium incarnatum L.); 2) poultry litter; 3) crimson clover + poultry litter; 4) ammonium nitrate $\left(\mathrm{NH}_{4} \mathrm{NO}_{3}\right)$; and 5) untreated control. Crimson clover provided from 20 to $75 \mathrm{~kg} \cdot \mathrm{ha}^{-1} \mathrm{~N}$ over the course of the two growing seasons; however, most of the available $\mathrm{N}$ from crimson clover became available late in the growing season. As a result, supplemental $\mathbf{N}$ may be required in spring where crimson clover is used as an orchard cover crop. Poultry litter, with and without clover, provided available $\mathbf{N}$ consistently throughout the growing season with more $\mathbf{N}$ becoming available later in the season than earlier. This suggests that poultry litter applications for pecan should be timed before budbreak. Under optimum environmental conditions, $\mathrm{N}$ from $\mathrm{NH}_{4} \mathrm{NO}_{3}$ is most available within the first 30 days of application. Thus, it appears that synthetic fertilizer applications using $\mathrm{NH}_{4} \mathrm{NO}_{3}$ as the $\mathbf{N}$ source should be targeted at or 2 to 3 weeks after pecan budbreak.
\end{abstract}

Pecans are commercially produced across a wide geographic range in 14 states within the United States, generating a crop valued at \$369 million [U.S. Department of Agriculture (USDA), 2010). Aside from the United States, pecans are also produced in Mexico, Brazil, Peru, Argentina, Australia, South Africa, Israel, and Egypt. Georgia lies outside the tree's native range but annually produces more pecans than any other state, comprising nearly $30 \%$ of the U.S. pecan crop annually (USDA, 2010).

Overfertilization can be more common in orchard crops than in many other crop species as a result of the increased likelihood of fertilizer $\mathrm{N}$ application during the dormant period of perennial crops. Excess $\mathrm{N}$ increases vegetative growth, which promotes shading and reduces flower bud development, fruit set, quality, and survival. Excessive levels of applied $\mathrm{N}$ can also lead to nutritional imbalances and increased susceptibility to insect and disease pests (Weinbaum et al., 1992).

Wood (2001) suggests many commercial orchards likely receive excess $\mathrm{N}$ fertilizer or timing of $\mathrm{N}$ application is suboptimal, resulting in inefficient use of applied $\mathrm{N}$ and excess $\mathrm{N}$ leaching through the soil profile. In the early

Received for publication 18 May 2011. Accepted for publication 6 July 2011.

This work was supported by the Georgia Agricultural Commodity Commission for Pecans.

I thank Del Taylor, Mike Crumley, Mike Hudson, and Cody Casey for technical assistance.

${ }^{1}$ To whom reprint requests should be addressed; e-mail1wells@uga.edu. years of the southeastern pecan industry, legumes and cow manure, provided by cattle grazing the orchards, were commonly used to provide fertilizer $\mathrm{N}$ for pecan trees. After World War II, pecan producers began using synthetic fertilizer on a large scale as a result of the relatively low cost and ease of application (White et al., 1981). As air-blast sprayers became available and more producers began applying fungicides and insecticides routinely, grazing cattle in the orchard was discontinued. Soaring energy costs have led to a dramatic increase in the cost of synthetic fertilizer (Huang, 2009). Between 2002 and 2007, the cost of fertilizer N per acre rose by over $200 \%$ (Wells, 2009a). This sharp increase in the cost of a single input dramatically reduces the profit margin for pecan producers.

Recent instability in fuel and fertilizer prices have led pecan producers to once again consider the use of various legumes such as crimson clover as an orchard floor cover to supplement tree $\mathrm{N}$ requirements. Smith et al. (1996) suggested that a combination of crimson clover and hairy vetch (Vicia villosa Roth) could be used as a cover crop to meet the $\mathrm{N}$ requirement of pecan. In 2005, clover (Trifolium sp.) was used in only $15 \%$ of surveyed pecan orchards in Georgia, but by 2008, nearly half of all pecan orchards surveyed used clover as an orchard floor cover (Wells, 2009b).

Georgia poultry farmers produce over 2 million tons of poultry litter (manure) annually (Ritz and Merka, 2009) in the production of meat and eggs, creating a need for disposal. Proper application of litter to the land as a soil amendment is an appropriate use for the waste product. The organic material and nutrients found in poultry litter are beneficial byproducts that have proven useful in amending agricultural soils (Mitchell and Tu, 2005).

Efficient $\mathrm{N}$ use partially depends on an understanding of the complex interactions of soil and crop management. Nitrogen fertilizer application to plants at rates not adjusted for the $\mathrm{N}$ contribution from soil organic $\mathrm{N}$ mineralization may result in overapplication of fertilizer. In addition, proper timing of $\mathrm{N}$ applications based on soil $\mathrm{N}$ dynamics and plant demand can play a large role in the efficient use of fertilizer $\mathrm{N}$. The in situ soil core technique can be helpful in evaluating management effects on $\mathrm{N}$ availability and provide information needed for improved nutrient management (Adams and Attiwill, 1986; Kolberg et al., 1997; Raison et al., 1987). There are few studies addressing $\mathrm{N}$ availability in pecan orchard soils. Reasonable estimates of soil $\mathrm{N}$ availability are needed to determine management influences on nutrient supply under orchard conditions. Therefore, the objective of this study was to measure $\mathrm{N}$ availability dynamics in a pecan orchard under various $\mathrm{N}$ fertilizer regimes on a southeastern U.S. Coastal Plain soil.

\section{Materials and Methods}

Study site, experimental design, and soil sampling. The study was conducted in a 25 year-old solid-set sprinkler irrigated pecan orchard on a $12.2 \mathrm{~m} \times 12.2-\mathrm{m}$ spacing located at the University of Georgia Tifton Campus Ponder Research Farm near Tifton, GA, from 2008 to 2010. Soil type was Fuquay loamy sand (loamy, siliceous, thermic Arenic Plinthic Paleudult). The orchard was managed under commercial conditions according to University of Georgia Cooperative Extension recommendations (Hudson et al., 2010). A 3.7-m wide herbicide strip was maintained with glyphosate along the tree row in all plots. Row middles consisted of bermudagrass (Cynodon dactylon L.) sod only except as indicated subsequently. The following treatments were evaluated: 1) crimson clover; 2) poultry litter; 3 ) crimson clover + poultry litter; 4) ammonium nitrate; and 5) untreated control. Treatments were arranged in a randomized complete block design using six replications. Each plot consisted of a $24.4 \mathrm{~m} \times 24.4-\mathrm{m}$ area centered on a single pecan tree. All plots were separated by untreated border plots. Individual plots received the same treatments in 2009 and 2010.

Crimson clover was broadcast-seeded annually over the bermudagrass sodded row middles beginning in Oct. 2007 at a rate of 33.6 $\mathrm{kg} \cdot \mathrm{ha}^{-1}$ to ensure a full stand in the crimson clover and crimson clover + poultry litter plots. Clover stand density was not measured; however, visual observation suggests that a full stand of clover was obtained. Non-composted poultry litter was applied at a rate of 2240 $\mathrm{kg} \cdot \mathrm{ha}^{-1}$ on 31 Mar. 2008, 31 Mar. 2009, and 29 Mar. 2010. This rate is reflective of that traditionally used by pecan growers in the southeastern United States. Poultry litter analysis for each year of study can be found in Table 1 . Ammonium nitrate $(34 \mathrm{~N}-0 \mathrm{P}-0 \mathrm{~K})$ was applied 
at a rate of $84 \mathrm{~kg} \mathrm{~N} /$ ha on 31 Mar. 2008, 31 Mar. 2009, and 29 Mar. 2010. This rate is considered a sufficient rate of $\mathrm{N}$ for southeastern pecan production because yield responses to higher rates are rarely observed in managed orchards (Worley, 2002). Zinc sulfate $\left(62.9 \mathrm{~kg} \cdot \mathrm{ha}^{-1}\right)$ and muriate of potash $\left(70.6 \mathrm{~kg} \cdot \mathrm{ha}^{-1}\right)$ were applied to all plots on 23 Mar. 2009. Plots with clover or poultry litter did not receive $\mathrm{N}$ from other fertilizer sources. All clover residue, poultry litter, and fertilizer were left undisturbed on the soil surface after application. The untreated control received no $\mathrm{N}$ fertilizer inputs.

Nitrogen availability was measured in intact soil cores using capped polyvinyl chloride (PVC) tubes (Adams and Attiwill, 1986) to minimize leaching and prevent plant uptake. This experiment was part of a larger study and measurements began 1 year after initial treatment application. Five PVC tubes $(5 \mathrm{~cm}$ in diameter, $30.5 \mathrm{~cm}$ long) were driven into the soil to a depth of $20.5 \mathrm{~cm}$ below the soil surface around four trees in each of the treatments described previously. Tubes in each plot were positioned $15.2 \mathrm{~cm}$ apart in a line parallel to the tree row beneath the drip line of the tree canopy $\approx 1 \mathrm{~m}$ outside the herbicide strip at $2.85 \mathrm{~m}$ from the tree trunk. In 2010 , four holes were drilled into the tube wall at $6.4 \mathrm{~cm}$ from the top of the tube to facilitate gas exchange between the air inside and outside the tube above the soil level. Tubes were placed in the orchard immediately after application of poultry litter and fertilizer (31 Mar. 2009 and 29 Mar. 2010). On the day of installation, one tube from each plot was removed immediately after installation. One tube per plot was removed again at 30,60, 120, and $240 \mathrm{~d}$ after installation.

After collection, tubes were transported to the laboratory where soil was passed through a 2-mm sieve, dried, and analyzed for nitrate $\mathrm{N}\left(\mathrm{NO}_{3}-\mathrm{N}\right)$ and ammonia $\mathrm{N}\left(\mathrm{NH}_{4}-\mathrm{N}\right)$. Soil $\mathrm{NO}_{3}$ and $\mathrm{NH}_{4}$ were determined by extraction with $0.1 \mathrm{~N}$ potassium chloride $(\mathrm{KCl})$ (Kissell and Sonon, 2008). $\mathrm{NO}_{3}-\mathrm{N}$ concentrations of the $\mathrm{KCl}$ extracts were analyzed colorimetrically with a Perstorp EnviroFlow 3000 Auto Analyzer (Perstop Analytical, Wilsonville, OR). $\mathrm{NH}_{4}-\mathrm{N}$ concentrations of the $\mathrm{KCl}$ extracts were analyzed colorimetrically using an Aquakem Discrete Photoanlyzer (EST Analytical, Fairfield, $\mathrm{OH}$ ).

Statistical analyses of data were performed with SAS (SAS Institute, Cary, NC). Analysis of variance was used to compare treatment effects. Means were separated using Duncan's multiple range test $(P<0.05)$.

\section{Results and Discussion}

During 2009, N availability increased in all treatments except the clover treatment between $30 \mathrm{~d}$ (May) and $60 \mathrm{~d}$ (June) after fertilizer and litter application (Table 2). A reduction in $\mathrm{N}$ availability occurred in all plots between $60 \mathrm{~d}$ (June) and $120 \mathrm{~d}$ (August) (Table 2). With the exception of the ammonium nitrate treatment, $\mathrm{N}$ availability in all treatments peaked at $240 \mathrm{~d}$ after application of fertilizer and litter or in December (Table 2).

Table 1. Mineral analysis of poultry litter used during 2008, 2009, and 2010. ${ }^{2}$

\begin{tabular}{rrrrrrrrrrrr}
\hline & \multicolumn{10}{c}{$\left(\mathrm{kg} \cdot \mathrm{t}^{-1}\right)$} \\
\hline & $\mathrm{N}$ & $\mathrm{P}$ & $\mathrm{K}$ & $\mathrm{Ca}$ & $\mathrm{Mg}$ & $\mathrm{S}$ & $\mathrm{Mn}$ & $\mathrm{Fe}$ & $\mathrm{B}$ & $\mathrm{Cu}$ & $\mathrm{Zn}$ \\
\hline 2008 & 34 & 7 & 14 & 14 & 3 & 3 & 0.2 & 0.5 & 0.01 & 0.2 & 0.2 \\
2009 & 28 & 28 & 31 & 22 & 5 & 5 & 0.2 & 2 & 0.03 & 0.4 & 0.3 \\
2010 & 27 & 27 & 30 & 20 & 5 & 5 & 0.2 & 2 & 0.02 & 0.4 & 0.3 \\
\hline
\end{tabular}

${ }^{\mathrm{z}}$ Measured nutrients were total (organic and inorganic) nitrogen $(\mathrm{N})$, phosphorous $(\mathrm{P})$, potassium $(\mathrm{K})$, magnesium $(\mathrm{Mg})$, calcium $(\mathrm{Ca})$, sulfur $(\mathrm{S})$, manganese $(\mathrm{Mn})$, iron $(\mathrm{Fe})$, boron $(\mathrm{B})$, copper $(\mathrm{Cu})$, and zinc $(\mathrm{Zn})$.

Table 2. Mean soil nitrate $\left(\mathrm{NO}_{3}\right)$, ammonia $\left(\mathrm{NH}_{4}\right)$, and total available nitrogen $\left(\mathrm{NH}_{4}+\mathrm{NO}_{3}\right)$ at the end of each incubation period and over the course of the growing season for clover, poultry litter, clover + poultry litter, ammonium nitrate, and control treatments during 2009.

\begin{tabular}{|c|c|c|c|c|}
\hline $\begin{array}{l}\text { Incubation period } \\
\text { (days after installation) }\end{array}$ & Treatment & $\mathrm{NO}_{3}\left(\mathrm{~kg} \cdot \mathrm{ha}^{-1}\right)$ & $\mathrm{NH}_{4}\left(\mathrm{~kg} \cdot \mathrm{ha}^{-1}\right)$ & $\begin{array}{c}\text { Total available } \\
\mathrm{N}\left(\mathrm{kg} \cdot \mathrm{ha}^{-1}\right)\end{array}$ \\
\hline \multirow[t]{5}{*}{$\overline{30 \mathrm{~d}}$} & Clover & $21.0 \mathrm{~b}^{\mathrm{z}}$ & $25.1 \mathrm{a}$ & $46.1 \mathrm{a}$ \\
\hline & Poultry litter & $39.0 \mathrm{ab}$ & $27.0 \mathrm{a}$ & $66.0 \mathrm{a}$ \\
\hline & Clover + litter & $13.8 \mathrm{~b}$ & $48.3 \mathrm{a}$ & $62.1 \mathrm{a}$ \\
\hline & Ammonium nitrate & $59.6 \mathrm{a}$ & $20.6 \mathrm{a}$ & $80.2 \mathrm{a}$ \\
\hline & Control & $13.1 \mathrm{~b}$ & $21.0 \mathrm{a}$ & $34.0 \mathrm{a}$ \\
\hline \multirow[t]{5}{*}{$60 \mathrm{~d}$} & Clover & $30.8 \mathrm{a}$ & $11.1 \mathrm{a}$ & $41.9 \mathrm{a}$ \\
\hline & Poultry litter & $55.5 \mathrm{a}$ & $16.7 \mathrm{a}$ & $72.2 \mathrm{a}$ \\
\hline & Clover + litter & $69.4 \mathrm{a}$ & $15.2 \mathrm{a}$ & $84.3 \mathrm{a}$ \\
\hline & Ammonium nitrate & $79.0 \mathrm{a}$ & $10.3 \mathrm{a}$ & $89.3 \mathrm{a}$ \\
\hline & Control & $23.1 \mathrm{~b}$ & $19.4 \mathrm{a}$ & $42.5 \mathrm{a}$ \\
\hline \multirow[t]{5}{*}{$120 \mathrm{~d}$} & Clover & $15.1 \mathrm{a}$ & $3.4 \mathrm{a}$ & $18.5 \mathrm{a}$ \\
\hline & Poultry litter & $29.1 \mathrm{a}$ & $5.0 \mathrm{a}$ & $34.1 \mathrm{a}$ \\
\hline & Clover + litter & $57.8 \mathrm{a}$ & $4.0 \mathrm{a}$ & $61.8 \mathrm{a}$ \\
\hline & Ammonium nitrate & $66.2 \mathrm{a}$ & $4.3 \mathrm{a}$ & $70.5 \mathrm{a}$ \\
\hline & Control & $23.3 \mathrm{a}$ & $3.0 \mathrm{a}$ & $26.3 \mathrm{a}$ \\
\hline \multirow[t]{5}{*}{$240 \mathrm{~d}$} & Clover & $23.9 \mathrm{a}$ & $26.9 \mathrm{a}$ & $50.8 \mathrm{a}$ \\
\hline & Poultry litter & $88.3 \mathrm{a}$ & $27.4 \mathrm{a}$ & $115.7 \mathrm{a}$ \\
\hline & Clover + litter & $71.1 \mathrm{a}$ & $27.7 \mathrm{a}$ & $98.8 \mathrm{a}$ \\
\hline & Ammonium nitrate & $32.1 \mathrm{a}$ & $29.1 \mathrm{a}$ & $61.2 \mathrm{a}$ \\
\hline & Control & $26.4 \mathrm{a}$ & $29.5 \mathrm{a}$ & $55.9 \mathrm{a}$ \\
\hline \multirow[t]{5}{*}{$\operatorname{Mean}^{y}$} & Clover & $22.7 \mathrm{bc}$ & $16.6 \mathrm{a}$ & $40.0 \mathrm{~b}$ \\
\hline & Poultry litter & $53.0 \mathrm{ab}$ & $19.0 \mathrm{a}$ & $72.0 \mathrm{a}$ \\
\hline & Clover + litter & $53.0 \mathrm{ab}$ & $23.8 \mathrm{a}$ & $76.8 \mathrm{a}$ \\
\hline & Ammonium nitrate & $59.2 \mathrm{a}$ & $16.0 \mathrm{a}$ & $75.3 \mathrm{a}$ \\
\hline & Control & $21.4 \mathrm{c}$ & $18.2 \mathrm{a}$ & $39.7 \mathrm{~b}$ \\
\hline
\end{tabular}

${ }^{\mathrm{z}}$ Means followed by the same letter are not different at $P<0.05$ by Duncan's multiple range test.

${ }^{y}$ Mean $=$ mean soil nitrate $\left(\mathrm{NO}_{3}\right)$, ammonia $\left(\mathrm{NH}_{4}\right)$, and total available $\mathrm{N}\left(\mathrm{NH}_{4}+\mathrm{NO}_{3}\right)$ for each treatment averaged across all incubation periods.

Nitrogen availability increased in all treatments except ammonium nitrate and the untreated control between $30 \mathrm{~d}$ and $60 \mathrm{~d}$ of fertilizer and poultry litter application or between May and June 2010 (Table 3). Plots receiving poultry litter exhibited a sharp increase in $\mathrm{N}$ availability between 60 and $120 \mathrm{~d}$ (June and Aug. 2010) after application. All treatments with the exception of the poultry litter and untreated control showed peak availability at $240 \mathrm{~d}$ after application or between August and December. Although potential available $\mathrm{N}$ below the $20.5-\mathrm{cm}$ tubes is not accounted for in this study, a high percentage of pecan feeder roots is found in the upper $21 \mathrm{~cm}$ of the soil profile (White and Edwards, 1978).

During both years of study, $\mathrm{NO}_{3}$ was responsible for the majority of the overall increase in available $\mathrm{N}$ in all plots throughout most of the growing season (Tables 2 and 3 ). Clover biomass measurements were not made during the course of the study; however, visual observations suggest that clover biomass production was similar for both years. During
2009, which was the second year after initial clover establishment, mean available $\mathrm{N}$ over the course of the year in the clover treatment was similar to that observed in the control treatment and a little over half that observed in all other treatments (Table 2). In 2010, mean available $\mathrm{N}$ was $45.3 \mathrm{~kg} \cdot \mathrm{ha}^{-1}$ for the clover treatment, which was $300 \%$ higher than for the control treatment (Table 3). This indicates that crimson clover released an average of $34 \mathrm{~kg} \cdot \mathrm{ha}^{-1}$ additional $\mathrm{N}$ to the soil in the third year after the initial clover planting. The variation in available $\mathrm{N}$ for the clover treatment between the 2 study years may be explained by denitrification, which can occur under wet conditions (Aulakh et al., 1991), as observed in Spring 2009. Perforation of tubes in 2010 may have also reduced the level of $\mathrm{N}$ loss observed in that year by enhancing aerobic conditions within the tubes. This is suggested by the lower $\mathrm{NH}_{4}$ levels in 2010 compared with 2009.

Mean available $\mathrm{N}$ in the poultry litter, clover + poultry litter, and ammonium nitrate treatments were similar in 2009 , providing 
Table 3. Mean soil nitrate $\left(\mathrm{NO}_{3}\right)$, ammonia $\left(\mathrm{NH}_{4}\right)$, and total available nitrogen $\left(\mathrm{NH}_{4}+\mathrm{NO}_{3}\right)$ at the end of each incubation period and over the course of the growing season for clover, poultry litter, clover + poultry litter, ammonium nitrate, and control treatments during 2010.

\begin{tabular}{|c|c|c|c|c|}
\hline $\begin{array}{l}\text { Incubation period } \\
\text { (days after installation) }\end{array}$ & Treatment & $\mathrm{NO}_{3}\left(\mathrm{~kg} \cdot \mathrm{ha}^{-1}\right)$ & $\mathrm{NH}_{4}\left(\mathrm{~kg} \cdot \mathrm{ha}^{-1}\right)$ & $\begin{array}{c}\text { Total available } \\
\mathrm{N}\left(\mathrm{kg} \cdot \mathrm{ha}^{-1}\right) \\
\end{array}$ \\
\hline \multirow[t]{5}{*}{$30 \mathrm{~d}$} & Clover & $23.2 \mathrm{a}^{\mathrm{z}}$ & $4.1 \mathrm{~b}$ & $27.3 \mathrm{~b}$ \\
\hline & Poultry litter & $33.5 \mathrm{a}$ & $4.1 \mathrm{~b}$ & $37.6 \mathrm{~b}$ \\
\hline & Clover + litter & $43.4 \mathrm{a}$ & $4.1 \mathrm{~b}$ & $47.5 \mathrm{ab}$ \\
\hline & Ammonium nitrate & $69.5 \mathrm{a}$ & $16.1 \mathrm{a}$ & $85.6 \mathrm{a}$ \\
\hline & Control & $14.3 \mathrm{~b}$ & $3.6 \mathrm{~b}$ & $17.9 \mathrm{~b}$ \\
\hline \multirow[t]{5}{*}{$60 \mathrm{~d}$} & Clover & $40.9 \mathrm{ab}$ & $2.9 \mathrm{a}$ & $43.8 \mathrm{ab}$ \\
\hline & Poultry litter & $42.9 \mathrm{ab}$ & $2.5 \mathrm{a}$ & $45.4 \mathrm{ab}$ \\
\hline & Clover + litter & $79.6 \mathrm{a}$ & $2.9 \mathrm{a}$ & $82.5 \mathrm{a}$ \\
\hline & Ammonium nitrate & $54.2 \mathrm{ab}$ & $8.1 \mathrm{a}$ & $62.3 \mathrm{ab}$ \\
\hline & Control & $11.6 \mathrm{~b}$ & $1.8 \mathrm{a}$ & $13.4 \mathrm{~b}$ \\
\hline \multirow[t]{5}{*}{$120 \mathrm{~d}$} & Clover & $33.4 \mathrm{a}$ & $2.2 \mathrm{~b}$ & $35.6 \mathrm{a}$ \\
\hline & Poultry litter & $96.6 \mathrm{a}$ & $3.2 \mathrm{ab}$ & $99.8 \mathrm{a}$ \\
\hline & Clover + litter & $96.4 \mathrm{a}$ & $4.0 \mathrm{a}$ & $100.4 \mathrm{a}$ \\
\hline & Ammonium nitrate & $66.4 \mathrm{a}$ & $2.2 \mathrm{~b}$ & $68.6 \mathrm{a}$ \\
\hline & Control & $1.4 \mathrm{~b}$ & $6.7 \mathrm{a}$ & $8.1 \mathrm{~b}$ \\
\hline \multirow[t]{5}{*}{$240 \mathrm{~d}$} & Clover & $70.4 \mathrm{a}$ & $4.2 \mathrm{a}$ & $74.6 \mathrm{a}$ \\
\hline & Poultry litter & $70.6 \mathrm{a}$ & $4.1 \mathrm{a}$ & $74.7 \mathrm{a}$ \\
\hline & Clover + litter & $117.0 \mathrm{a}$ & $5.5 \mathrm{a}$ & $122.5 \mathrm{a}$ \\
\hline & Ammonium nitrate & $99.6 \mathrm{a}$ & $5.5 \mathrm{a}$ & $105.1 \mathrm{a}$ \\
\hline & Control & $3.1 \mathrm{~b}$ & $2.8 \mathrm{a}$ & $5.9 \mathrm{~b}$ \\
\hline \multirow[t]{5}{*}{ Mean $^{y}$} & Clover & $42.0 \mathrm{bc}$ & $3.4 \mathrm{a}$ & $45.3 \mathrm{~b}$ \\
\hline & Poultry litter & $60.9 \mathrm{ab}$ & $3.5 \mathrm{a}$ & $64 \mathrm{ab}$ \\
\hline & Clover + litter & $84.1 \mathrm{a}$ & $4.1 \mathrm{a}$ & $88.2 \mathrm{a}$ \\
\hline & Ammonium nitrate & $72.4 \mathrm{ab}$ & $8.0 \mathrm{a}$ & $80.4 \mathrm{ab}$ \\
\hline & Control & $7.6 \mathrm{c}$ & $3.7 \mathrm{a}$ & $11.3 \mathrm{c}$ \\
\hline
\end{tabular}

${ }^{\mathrm{z}}$ Means followed by the same letter are not different at $P<0.05$ by Duncan's multiple range test.

${ }^{\mathrm{y}}$ Mean $=$ mean soil nitrate $\left(\mathrm{NO}_{3}\right)$, ammonia $\left(\mathrm{NH}_{4}\right)$, and total available $\mathrm{N}\left(\mathrm{NH}_{4}+\mathrm{NO}_{3}\right)$ for each treatment averaged across all incubation periods.

$81 \%, 93 \%$, and $90 \%$ more available $\mathrm{N}$, respectively, than did the clover and control treatments (Table 2). In 2010, poultry litter alone provided $466 \%$ more available $\mathrm{N}$ than the control treatment. Clover + poultry litter increased mean available $\mathrm{N}$ by $680 \%$ over the control. Ammonium nitrate provided an increase in available $\mathrm{N}$ of $611 \%$ over the control (Table 3).

Varied results on the effect of fertilizer application timing have been observed for pecan. One study reported no effect of fertilizer application timing on pecan yield (Hunter and Lewis, 1942). Hunter and Hammar (1957) demonstrated similar pecan yields from complete fertilizers applied at different times. Hunter (1964) found no difference in tree response between December and February application. Another study found a varying cultivar effect on response of pecan tree yield to $\mathrm{N}$ and phosphorus fertilizer timing (Smith et al., 1995). Goff et al. (2001) reported enhanced yield with an additional late-season fertilizer application in Alabama. Despite these varied results, common fertilizer practices for commercial pecan production in the southeastern United States are to apply $\mathrm{N}$ fertilizer in split applications in April and June; April and late August to early September; or in April, June, and August to September.

The major period of $\mathrm{N}$ accumulation in pecan occurs as new leaves, shoots, and flowers are developing in the spring (Acuna-Maldonado et al., 2003). Pecan trees preferentially use stored $\mathrm{N}$ during the initial spring canopy
(Acuna-Maldonado et al., 2003) and orchard soil $\mathrm{N}$ dynamics, it appears that synthetic fertilizer applications using ammonium nitrate as the N source should be targeted at or 2 to 3 weeks after pecan budbreak. This would allow for the rapid uptake of available $\mathrm{N}$ when the $\mathrm{N}$ demand of pecan trees is at its peak.

Although pecan orchard soil $\mathrm{N}$ availability under each of the treatments studied may vary depending on environmental conditions, crimson clover provided from 20 to $75 \mathrm{~kg} \cdot \mathrm{ha}^{-1} \mathrm{~N}$ over the course of the two growing seasons (Tables 2 and 3), suggesting that crimson clover can provide supplemental $\mathrm{N}$ for pecan trees as previously demonstrated by Smith et al. (1996) in Oklahoma. This would allow pecan producers to reduce the amounts of applied synthetic $\mathrm{N}$ fertilizer used in the orchard. However, most of the mineralized $\mathrm{N}$ from crimson clover became available later in the growing season after the clover had senesced and the tissue was broken down by microorganisms (Tables 1 and 2).

Crimson clover generates considerable biomass, which is mowed after seed maturation and remains on the orchard floor in southeastern pecan orchard systems (Wells, 2007). Such a high residue situation can result in a buildup of organic matter, stratification of nutrients, and accumulation of surface residue (Hargrove, 1986), which can temporarily immobilize $\mathrm{N}$ and thus reduce $\mathrm{N}$ availability (Rice and Smith, 1984). These results suggest that although crimson clover can provide supplemental, late-season $\mathrm{N}$ for pecan orchard soils, orchards using crimson clover would likely benefit from a spring application of synthetic $\mathrm{N}$ based on pecan $\mathrm{N}$ absorption patterns and current $\mathrm{N}$ recommendations for pecan (Wells, 2007). These measurements were made in Years 2 and 3 of initial clover establishment and would appear to support conclusions by Ladd et al. (1981) that the value of legume residues as a source of $\mathrm{N}$ is long term and involves maintaining soil $\mathrm{N}$ concentrations at adequate levels.

Management practices, including the use of clover cover crops, that accumulate or increase soil organic matter enhance the intrinsic ability of the soil to supply inorganic $\mathrm{N}$ through mineralization over time (Wilson et al., 2001). In addition, high residue cover crops can buffer asynchrony between nutrient availability and plant nutrient demand by gradually releasing previously immobilized nutrients during the growing season (Magdoff and Weil, 2004). It is important to recognize that application of $\mathrm{N}$ fertilizer to clover can reduce or eliminate $\mathrm{N}$ fixation by clover. Therefore, any spring $\mathrm{N}$ applications to orchards using clover should be directed toward orchard herbicide strips to minimize this effect.

Poultry litter, with and without clover, provided available $\mathrm{N}$ consistently throughout the growing season with more $\mathrm{N}$ being available later in the season than earlier in the year (Tables 2 and 3). This suggests that poultry litter applications should be timed before budbreak from late February to mid-March, well ahead of the peak $\mathrm{N}$ demand of pecan trees. In addition, it appears that the availability 
of $\mathrm{N}$ from poultry litter increases with time. This supports previous studies in agronomic crops, which have demonstrated that poultry litter becomes available more slowly than synthetic fertilizer as a result of the mineralizing activity of soil microorganisms (Mitchell and Tu, 2005). Wells (2011) has previously demonstrated that both clover and, under certain conditions, poultry litter enhance soil organic matter and microbial activity in southeastern pecan orchard systems. The poultry litter used in the current study was non-composted litter. Previous studies have shown that the composting process immobilizes $\mathrm{N}$ in the litter and produces humus that can be used as a source of organic materials and slows the release of N (Paul and Clark, 1996). Thus, the initial availability of $\mathrm{N}$ from composted litter would likely be delayed compared with that of non-composted litter.

In summary, each of the $\mathrm{N}$ fertilizer regimes examined in the current study has merit as a component of pecan $\mathrm{N}$ fertilization programs. To time $\mathrm{N}$ fertilizer applications to best meet the pecan tree's primary demand, applications of ammonium nitrate should be timed at or soon after pecan budbreak, depending on tree $\mathrm{N}$ reserve status and soil $\mathrm{N}$ availability. Pecan producers using crimson clover as a groundcover should continue to supply $\mathrm{N}$ in another form during early spring because a large percentage of $\mathrm{N}$ from the clover crop is unavailable until later in the growing season. However, crimson clover can provide substantial supplemental $\mathrm{N}$, which can help reduce fertilization costs by reducing the overall application amount required. Synthetic $\mathrm{N}$ applied in spring to orchards using clover should be directed toward herbicide strips to minimize the effect of applied $\mathrm{N}$ on $\mathrm{N}$ fixation by clover. Properly timed applications of poultry litter can also provide $\mathrm{N}$ for pecan trees during their peak demand and throughout the growing season. This information can help pecan producers better time fertilizer applications to maximize $\mathrm{N}$ use efficiency by pecan trees.

\section{Literature Cited}

Acuna-Maldonado, L.E., M.W. Smith, N.O. Maness, B.S. Cheary, and B.L. Carroll. 2003. Influence of nitrogen application time on nitrogen absorption, partitioning, and yield of pecan. J. Amer. Soc. Hort. Sci. 128:155-162.

Adams, M.A. and M.P. Attiwill. 1986. Nutrient cycling and nitrogen mineralization in eucalypt forests of southeastern Australia. Plant Soil 92:341-362.

Aulakh, M.S., J.W. Doran, D.T. Walters, A.R. Mosier, and D.D. Francis. 1991. Crop residue type and placement effects on denitrification and mineralization. Soil Sci. Soc. Amer. J. 55:1020-1025.

Goff, W., M. Nesbitt, and C. Browne. 2001. Late season fertilization: An exciting new development for the pecan industry. Proc. Southeastern Pecan Growers Assn. 94:91-93.

Hargrove, W.L. 1986. Winter legumes as a nitrogen source for no-till grain sorghum. Agron. J. 78:70-74.

Huang, W. 2009. Factors contributing to the recent increase in U.S. fertilizer prices, 2002-2008. U.S. Dept. of Agr. Economic Research Service., AR-33. 8 Apr. 2011. <http://www.ers. usda.gov/Publications/AR33/AR33.pdf $>$.

Hudson, W., J. Brock, S. Culpepper, and L. Wells. 2010. Georgia pecan pest management guide. Univ. Georgia Coop. Ext. Bull. 841.

Hunter, J.H. 1964. Time of applying nitrogen to pecan trees in sod. Proc. Southeastern Pecan Growers Assn. 57:18-22.

Hunter, J.H. and H.E. Hammar. 1957. Variation in composition of pecan leaves. Better Crops Plant Food 41:18-25.

Hunter, J.H. and R.D. Lewis. 1942. Influence of fertilizer and time of its application on growth, yield, and quality of pecans. J. Amer. Soc. Agron. 34:175-187.

Kissell, D.E., and L. Sonon. 2008. Soil test handbook for Georgia. Univ. Georgia Coop. Ext. Special Bul. 62.

Kolberg, R.L., B. Rouppet, D.G. Westfall, and G.A. Peterson. 1997. Evaluation of an in situ net soil nitrogen mineralization method in dryland agroecosystems. Soil Sci. Soc. Amer. J. 61:504-508.

Kraimer, R.A., W.C. Lindemann, and E.A Herrera. 2001. Distribution of ${ }^{15} \mathrm{~N}$ labeled fertilizer applied to pecan: A case study. HortScience 36:308-312.

Kraimer, R.A., W.C. Lindeman, and E.A. Herrera 2004. Recovery of late season ${ }^{15} \mathrm{~N}$ labeled fertilizer applied to pecan. HortScience 39: 256-260.

Ladd, J.N., J.M. Oades, and M. Amato. 1981 Distribution and recovery of nitrogen from legume residues decomposing in soils sown to wheat in the field. Soil Biol. Biochem. 13:251256.

Magdoff, F. and R.R. Weil. 2004. Soil organic matter in sustainable agriculture. CRC Press, Boca Raton, FL.

Mitchell, C.C. and S. Tu. 2005. Long term evaluation of poultry litter as a source of nitrogen for cotton and corn. Agron. J. 97:399-407.

Paul, E.A. and F.E. Clark. 1996. Soil microbiology and biochemistry. Academic Press, San Diego, CA.
Raison, R.J., M.J. Connell, and P.K. Khanna. 1987. Methodology for studying fluxes of soil inorganic $\mathrm{N}$ in situ. Soil Biol. Biochem. 19:521-530.

Rey, A., W.C. Lindemann, and M.D. Remmenga. 2006. Recovery of ${ }^{15} \mathrm{~N}$ fertilizer applied at different stages of pecan kernel fill. HortScience 41:794-798.

Rice, C.W. and M.S. Smith. 1984. Short-term immobilization of fertilizer $\mathrm{N}$ at the surface of no till soils. Soil Sci. Soc. Amer. J. 47:11251129.

Ritz, C.W. and W.C. Merka. 2009. Maximizing poultry litter manure use through nutrient management planning. Univ. Georgia Coop. Ext. Bul. 1245

Smith, M.W., B. Cheary, and B. Carroll. 1995. Time of nitrogen application and phosphorous effects on growth, yield, and fruit quality of pecan. HortScience 30:532-534.

Smith, M.W., A. Shiferaw, and N.R. Rice. 1996. Legume cover crops as a nitrogen source for pecan. J. Plant Nutr. 19:1117-1130.

U.S. Department of Agriculture. 2010. Noncitrus fruits and nuts: 2009 summary. Natl. Agr. Stat. Serv., U.S. Dept. Agr., Washington, DC.

Weinbaum, S.A., R.S. Johnson, and T.M. DeJong. 1992. Causes and consequences of overfertilization in orchards. HortTechnology 2:112-121.

Wells, M.L. (ed.). 2007. Southeastern pecan growers handbook. Univ. Georgia Coop. Ext. Pub. 1327.

Wells, M.L. 2009a. Poultry litter budget for Georgia. Proc. Southeastern Pecan Growers Assn. 102:122-128.

Wells, M.L. 2009b. Pecan nutrient element status and orchard soil fertility in the southeastern United States coastal plain. HortTechnology 19:432-438.

Wells, M.L. 2011. Response of pecan orchard soil chemical and biological quality indicators to poultry litter application and clover cover crops. HortScience 46:306-310.

White, A.W., E.R. Beatty, and W.L. Tedders. 1981. Legumes as a source of nitrogen and effects of management practices on legumes in pecan orchards. Proc. Southeastern Pecan Growers Assn. 74:97-106.

White, A.W. and J.H. Edwards. 1978. Soil profile distribution and seasonal growth of pecan roots. Proc. Southeastern Pecan Growers Assn. 71:47-53.

Wilson, T., E.A. Paul, and R.R. Harwood. 2001 Biologically active soil organic matter fractions in sustainable cropping systems. Appl. Soil Ecol. 16:63-76.

Worley, R.E. 2002. Compendium of pecan production and research. Edwards Brothers Press, Ann Arbor, MI

Wood, B.W. 2001. Managing nitrogen in pecan orchards. Proc. Southeastern Pecan Growers Assn. 94:153-159. 